\title{
Questionable benefit of being in hospital after procedure for patients without immediate adverse events in EUS-guided drainage of pancreatic pseudocysts
}

\author{
Félix I. Téllez-Ávila ${ }^{1,2}$, Luis Eduardo Casasola-Sánchez ${ }^{1}$, Angela Sau11,2, Carlos Chan ${ }^{1,3}$, \\ Jorge Hernández-Calleros ${ }^{1,4}$, Miguel Ángel Ramírez-Luna ${ }^{1,2}$ and Luis Uscanga-Domínguez ${ }^{1,4}$ \\ ${ }^{1}$ Pancreas Clinic; ${ }^{2}$ Department of Gastrointestinal Endoscopy; ${ }^{3}$ Surgery; ${ }^{4}$ Department of Gastroenterology. Instituto Nacional de Ciencias Médicas \\ y Nutrición Dr. Salvador Zubirán, Mexico City, México.
}

\begin{abstract}
Introduction: There is no consensus about if patients with EUS-guided drainage (EUS-GD) of pancreatic pseudocyst (PPC) could be discharged the same day or if the patient must stay at least one night in hospital. The aim was to report adverse events rate in the first $24 \mathrm{~h}$ after the procedure of patients with PPC treated by EUS-GD. Materials and Methods: $A$ retrospective analysis of data obtained prospectively was conducted. Patients with PPC were included in the study. EUS-GD was using two double pigtail plastic stents ( $7 F$ and $4 \mathrm{~cm}$ ). Results: $A$ total of 31 procedures in 29 patients with PPC were analyzed. There were $16(55.2 \%)$ men with a mean $\pm S D$ age of $42.5 \pm 14.5$ years. The endoscopic drainage was performed through transgastric in 23/29 (79.3\%) patients and transduodenal in 6/29 (17.2\%) patients. Technical success was $100 \%$, clinical success was $27 / 29$ (93.1\%), and three (10.3\%) patients had recurrence. In total, 5/31 (16.1\%) procedures have adverse events. One patient had stent migration after 24-month follow-up, two patients had infection of PPC after the punctuation (at day 4 and 5 after procedure), and two patients who bled during endoscopic drainage (one of them was successfully treated endoscopically with clips and the second required surgery). Conclusion: There is not a clear reason because patients with PPC and EUS-GD need for staying one night in hospital if was not any adverse event during the procedure.
\end{abstract}

Key words: México. EUS-guided drainage. Pancreatic pseudocyst.

\section{Correspondence:}

*Félix I. Téllez-Ávila

Department of Endoscopy

Instituto Nacional de Ciencias Médicas y

Nutrición Salvador Zubirán

Vasco de Quiroga, 15

Col. Belisario Domínguez, Sección XVI, Del. Tlalpan

C.P. 14080 , Mexico City, Mexico

Fecha de recepción: 01-09-2018

Fecha de aceptación: 20-11-2018 DOI: 10.24875/END.M19000001
Disponible en internet: 05-02-2019 Endoscopia. 2019;31:34-39 www.endoscopia-ameg.com 0188-9893/๑ 2019. Asociación Mexicana de Endoscopia Gastrointestinal, publicado por Permanyer México SA de CV, todos los derechos reservados. 


\section{Beneficio cuestionable de estar en el hospital después del procedimiento para pacientes sin eventos adversos inmediatos en el drenaje guiado por USE de pseudoquistes pancreáticos}

\section{Resumen}

Introducción: No hay consenso acerca de si los pacientes con pseudoquiste pancreático $(P Q P)$ con drenaje guiado por EUS (EUS-GD) podrían ser dados de alta el mismo día o si el paciente debe permanecer al menos una noche en el hospital. El objetivo fue informar la tasa de eventos adversos en las primeras 24 horas después del procedimiento. Material y métodos: Se realizó un análisis retrospectivo de datos obtenidos prospectivamente. Se incluyeron pacientes con PQP. Los EUS-GD utilizaron dos endoprótesis de plástico de doble cola de cochino (7F X $4 \mathrm{~cm}$ ). Resultados: se analizaron un total de 31 procedimientos en 29 pacientes con PQP. Se incluyeron 16 (55.2\%) hombres con una media $\pm D E$ de edad $42.5 \pm 14.5$ años. El drenaje se realizó por vía transgástrica en $23 / 29$ pacientes (79,3\%) y transduodenal en 6/29 pacientes (17,2\%). El éxito técnico fue del 100\%, el éxito clínico fue de $27 / 29(93,1 \%)$ y $3(10,3 \%)$ pacientes tuvieron recurrencia. En total, 5/31 (16.1\%) procedimientos tuvieron eventos adversos. Un paciente tuvo una migración del stent después de 24 meses de seguimiento, dos pacientes tuvieron una infección del PQP después de la punción (en los días 4 y 5 después del procedimiento) y dos pacientes con hemorragia durante el drenaje endoscópico (uno de ellos se trató con éxito con endoscopia con clips y el segundo requirió cirugía). En conclusión, no hay una razón clara por la cual los pacientes con EUS-GD de PQP necesitan quedarse hospitalizados si no hubo ningún evento adverso durante el procedimiento.

Palabras clave: México. Drenaje guiado por ultrasonido endoscópico. Pseudoquiste pancreático.

\section{Introduction}

Endoscopic ultrasound-guided drainage (EUS-GD) is replacing surgical treatment of pancreatic pseudocysts (PPC) ${ }^{1}$ regardless that now there is agreement that endoscopic treatment must be the first line therapy for $\mathrm{PPC}^{2-5}$, there are some unanswered questions. There is no consensus about if patients with EUS-GD of PPC could be discharged the same day or if the patient must stay at least one night in hospital. Many endosonographers leave patients in hospital, regardless, they are asymptomatic after procedure and others prefer to discharge the patient the same day of the procedure. In an email survey made by one of the authors (free-trade agreements [FTA]) with six top endosonographers around the world (France, the United States, Canada, and Brazil), four of six endosonographers prefer to discharge the patient to home the day after the procedure, regardless, they are asymptomatic. Two of the endosonographers consulted also recommend that antibiotics should be given up to 7 days after drainage. This is an important topic because space in the third level hospitals and costs. The aim was to report adverse events rate in the first $24 \mathrm{~h}$ after procedure of patients with PPC treated by EUS-GD with focus in the question about if to stay for one night in hospital could represent some benefit to patients.

\section{Materials and methods}

A retrospective analysis of data obtained prospectively was conducted. Patients were seen from 2008 to
2014 at the National Institute of Medical Sciences and Nutrition Salvador Zubirán at Mexico City, Mexico. PPC was defined as a fluid collection in the pancreatic/peripancreatic area that had a well-defined wall and contained no solid debris or recognizable parenchymal necrosis ${ }^{6}$. All patients gave their written informed consent before the procedure and all were evaluated routinely with a contrast-enhanced computed tomography (CT) scan before the procedure. Patients were intubated and received prophylactic antibiotics before the procedure ( $1 \mathrm{~g}$ I.V. of ceftazidime $30 \mathrm{~min}$ before). A convex linear array echoendoscope was used and once the PPC was identified, it was accessed using a 19-gauge needle (Echo-Tip, Wilson-Cook Medical, Inc., Winston Salem, North Carolina, USA) and a 0.035 -inch guidewire was inserted through the needle into the pseudocyst with fluoroscopic guidance. After removal of the needle, we used a needle knife inserted over the guidewire to create a bigger fistula. Finally, the gastric wall was dilated up to $12-15 \mathrm{~mm}$ and two double pigtail plastic stents $(7 \mathrm{~F}$ and $4 \mathrm{~cm}$ ) were deployed for drainage. The procedure was performed in both inpatients and outpatients. In those outpatients, they were observed at least every $4 \mathrm{~h}$ and discharged once they were awake and asymptomatic. Decision about if one particular patient was discharged the same day of procedure or if the patient stayed one night in hospital was based on criteria of the treating physician.

We consider complications as follows: perforation was diagnosed when pneumoperitoneum was evident 
on imaging studies associated with peritoneal signs. Bleeding was defined as any hemorrhagic event that required endotherapy, blood product transfusion, or inpatient observation. Infection was considered if any septic event occurred after the initial endoscopic drainage and was caused by contamination of PPC, proven by new-onset fever, positive blood cultures, or by positive fluid cultures obtained at endoscopic revision ${ }^{5,7}$. Stent migration was defined as the need to retrieve a stent from within the pseudocyst or the enteral lumen ${ }^{8}$. 8 weeks after the drainage, an endoscopic retrograde pancreatography or magnetic resonance cholangiopancreatography was performed. Partial ductal disruption was defined as extravasation of contrast from the main pancreatic duct (MPD) with opacification of PD proximal to the disruption ${ }^{9,10}$. An abrupt cutoff of MPD with or without contrast extravasation, or an inability to traverse this disconnection with a guidewire, was diagnostic of disconnected pancreatic duct syndrome ${ }^{11}$.

Clinical success was defined as complete resolution or a decrease in size of the PPC to $2 \mathrm{~cm}$ or smaller on $\mathrm{CT}$ associated with the resolution of symptoms at the 8-week outpatient follow-up evaluation ${ }^{2}$. Recurrence was defined as PPC found on CT associated with symptoms after an initial resolution ${ }^{2}$. Reintervention was defined as the need for repeat surgery or endoscopy due to persistent symptoms in association with a residual pseudocyst that was not $<50 \%$ of the original size on follow-up imaging ${ }^{2}$.

\section{Statistical analysis}

Continuous variables were expressed as means and SD. Categorical data were expressed as absolute numbers and percentages. Differences between groups were analyzed for categorical variables with the Chi-square test, except where the frequency was $<5$, in which Fisher's exact test was used. For continuous variables, analysis with Mann-Whitney $U$-test was done. We considered $p<0.05$ as statistically significant. Statistical analysis was performed with SPSS version 20.0 for Mac (SPSS Inc., Chicago, EEUU).

\section{Results}

A total of 31 procedures in 29 patients with PPC were analyzed. There were 16 (55.2\%) men and 13 (44.8\%) women with a mean \pm SD age of $42.5 \pm 14.5$ years. Gallstones were the most common etiology of pancreatitis with $15 / 29(51.7 \%)$ cases. The average diameter of
Table 1. Baseline clinical characteristics of patients included in the study

\begin{tabular}{|l|c|}
\hline Characteristic & $n=29(\%)$ \\
\hline Male & $16(55.2)$ \\
\hline Age, years & $42.5 \pm 14.5$ \\
\hline BMI & $24.2 \pm 4.1$ \\
\hline Comorbidities & $16(55.2)$ \\
\hline Cause of pancreatitis & \\
\hline Gallstones & $15(51.7)$ \\
\hline $\begin{array}{l}\text { Alcohol } \\
\text { Hypertriglyceridemia } \\
\text { Idiopathic }\end{array}$ & $6(20.7)$ \\
\hline Unspecified & $2(6.9)$ \\
& $1(3.4)$ \\
\hline
\end{tabular}

BMI: body mass index calculated by dividing the patient's body weight by the square of their height expressed as $\mathrm{kg} / \mathrm{m}^{2}$, PPC: pancreatic pseudocyst.

PPC was $9.6 \mathrm{~cm}$ (range $4.5-33 \mathrm{~cm}$ ). Table 1 summarizes the baseline clinical characteristics of patients.

The endoscopic drainage with EUS guidance was performed through transgastric in $23 / 29(79.3 \%)$ patients and transduodenal in 6/29 (17.2\%) patients. The mean number of stents used was 2 (1-4). 12 (41.3\%) patients required a nasocystic catheter because of infected PPC. In one patient, a metallic stent was used. The location of PPC in the 29 patients was the pancreatic body in $9(31 \%)$, body-tail in $8(27.6 \%)$, head in $5(17.2 \%)$, tail in $2(6.9 \%)$, uncinate region in $2(6.9 \%)$, and head-body in $2(6.9 \%)$. In one patient, PPC location was not specified. Technical success was $100 \%$, clinical success was $27 / 29(93.1 \%)$, and three (10.3\%) patients had recurrence. In total, 5/31 (16.1\%) procedures have adverse events (Table 2).

\section{SteNT MIGRATION}

One patient had stent migration after 24-month follow-up; in this case, PPC resolved, and in CT, one stent was detected in the small bowel at ileum. Due to intermittent abdominal pain, a double-balloon enteroscopy was performed; this found the stent $30 \mathrm{~cm}$ from the ileocecal valve and enabled retrieval of them with a polypectomy loop, with improvement on follow-up.

\section{INFECTION}

The first patient was a male of 36 years old with PPC of $15 \mathrm{~cm}$ in the head of the pancreas who back to the emergency department because chills and fever at day 
Table 2. Patients with adverse events related to EUS-GD of PPC

\begin{tabular}{|l|l|l|l|l|l|l|l|l|l|}
\hline Patient & Sex/age & Complication & $\begin{array}{l}\text { Size of } \\
\text { PPC, } \mathbf{c m}\end{array}$ & $\begin{array}{l}\text { Time from } \\
\text { procedure }\end{array}$ & $\begin{array}{l}\text { Need for } \\
\text { hospitalization }\end{array}$ & $\begin{array}{l}\text { Need for } \\
\text { surgery }\end{array}$ & $\begin{array}{l}\text { Days of } \\
\text { follow-up }\end{array}$ & Outcome & Reintervention \\
\hline 1 & F/46 & Bleed & 13 & During procedure & Yes & Yes & 760 & Alive & No \\
\hline 2 & F/74 & $\begin{array}{l}\text { Migration of } \\
\text { stent }\end{array}$ & 8 & 2 years & No & No & 730 & Alive & Yes* \\
\hline 3 & M/44 & Infection & 15 & & Yes & No & 1825 & Alive & Yes \\
\hline 4 & F/33 & Bleed & 16 & During procedure & Yes & No & 720 & Alive & No \\
\hline 5 & M/36 & Infection & 15 & 5 days & Yes & No & 670 & Alive & Yes \\
\hline
\end{tabular}

*Need for enteroscopy for to get the prosthesis.

**Need for new EUS procedure.

†Patient was discharged the next day without another adverse event.

Table 3. Complications reported in previous studies of EUS-guided drainage of pancreatic pseudocysts

\begin{tabular}{|c|c|c|c|c|c|}
\hline Author/year & $\mathbf{N}$ & Complications n, $(\%)$ & Type complication & Time after procedure & Treatment \\
\hline Krüger 2006 & 35 & $11(31)$ & $\begin{array}{l}\text { Cyst infection (4) } \\
\text { Stent occlusion (4) } \\
\text { Limited stent } \\
\text { drainage (3) }\end{array}$ & - & Endoscopy \\
\hline $\begin{array}{l}\text { Varadarajulu } \\
2008\end{array}$ & 20 & 0 & - & - & - \\
\hline Itoi $2008^{15}$ & 13 & 0 & - & - & - \\
\hline Yasuda 2009 & 26 & 0 & - & - & - \\
\hline $\begin{array}{l}\text { Varadarajulu } \\
2011\end{array}$ & 20 & 0 & - & - & - \\
\hline Sadik $2011^{16}$ & 16 & $1(6)$ & Perforation & 2 days & Surgery \\
\hline $\begin{array}{l}\text { Varadarajulu } \\
2011\end{array}$ & 148 & $8(5.4)$ & $\begin{array}{l}\text { Perforation (2) } \\
\text { Bleeding (1) } \\
\text { Stent migration (1) } \\
\text { Infection (4) }\end{array}$ & $\begin{array}{l}<24 \mathrm{~h}(3) \\
\text { not specified (4) } \\
1 \text { week (1) }\end{array}$ & $\begin{array}{l}\text { Surgery (5) } \\
\text { Endoscopy (3) }\end{array}$ \\
\hline Puri $2012^{17}$ & 40 & $3(7.5)$ & $\begin{array}{l}\text { Bleeding (1) } \\
\text { Infection (1) } \\
\text { Perforation (1) }\end{array}$ & $\begin{array}{l}\text { Inmediatly (2) } \\
40 \mathrm{~h} \mathrm{(1)}\end{array}$ & $\begin{array}{l}\text { Surgery (1) } \\
\text { Conservative (2) }\end{array}$ \\
\hline $\begin{array}{l}\text { Seewald } \\
2012^{* 18}\end{array}$ & 80 & $21(26)$ & $\begin{array}{l}\text { Bleeding (12) } \\
\text { Perforation (7) } \\
\text { Portal air-embolis (1) } \\
\text { Ogilvie Syndrome (1) }\end{array}$ & $\begin{array}{l}\text { Inmediatly (19) } \\
\text { Not specified (2) }\end{array}$ & $\begin{array}{l}\text { Surgery (4) } \\
\text { Conservative (5) } \\
\text { Self-limited (11) } \\
\text { Endoscopy (1) }\end{array}$ \\
\hline Wen 2014 & 118 & $23(19.5)$ & $\begin{array}{l}\text { Bleeding } \\
\text { Infection } \\
\text { Migration }\end{array}$ & - & - \\
\hline Siddiqui 2013 & 87 & $11(12)$ & $\begin{array}{l}\text { Bleeding (5) } \\
\text { Pain (3) } \\
\text { Fever (1) } \\
\text { Stent migration (2) }\end{array}$ & $\begin{array}{l}\text { Inmediatly (5) (bleeding) } \\
48-72 \mathrm{~h}(4) \\
1 \text { month (2) }\end{array}$ & $\begin{array}{l}\text { Embolization by } \\
\text { radiology (1) } \\
\text { Self-limited ( } 8 \text { ) } \\
\text { Endoscopically (2) }\end{array}$ \\
\hline Kwon $2013^{19}$ & 12 & $5(41)$ & $\begin{array}{l}\text { Fever (3) } \\
\text { Stent migration (2) }\end{array}$ & $\begin{array}{l}2 \text { months ( } 1 \text { stent) } \\
8 \text { months ( } 1 \text { stent) } \\
4-6 \text { weeks ( } 2 \text { fever) }\end{array}$ & $\begin{array}{l}\text { Pancreatic stent (2) } \\
\text { Stent replacemente (1) } \\
\text { Nothing (2 stent } \\
\text { migration) }\end{array}$ \\
\hline Shah 2015 & 33 & $5(15)$ & $\begin{array}{l}\text { Pain (3) } \\
\text { Stent migration (1) } \\
\text { Infection (1) }\end{array}$ & - & - \\
\hline
\end{tabular}


Table 3. Complications reported in previous studies of EUS-guided drainage of pancreatic pseudocysts (Continued)

\begin{tabular}{|l|c|c|l|l|l|}
\hline Author/year & N & Complications n, (\%) & Type complication & Time after procedure & Treatment \\
\hline Kokosis 2015 & 65 & $11(17)$ & $\begin{array}{l}\text { Infection (4) } \\
\text { Perforation (5) } \\
\text { Stent migration (1) } \\
\text { Bleeding (1) }\end{array}$ & $\begin{array}{l}24 \mathrm{~h} \mathrm{(1)} \\
\text { Inmediatly (5) } \\
\text { Not specifed (5) }\end{array}$ & $\begin{array}{l}\text { Surgery (3) } \\
\text { Self-limited (1) } \\
\text { Conservative (6) } \\
\text { Radiology (1) }\end{array}$ \\
\hline Kokosis 2015 & 65 & $11(17)$ & $\begin{array}{l}\text { Infection (4) } \\
\text { Perforation (5) } \\
\text { Stent migration (1) } \\
\text { Bleeding (1) }\end{array}$ & $\begin{array}{l}\text { In h (1) } \\
\text { Inmediatly (5) }\end{array}$ & $\begin{array}{l}\text { Surgery (3) } \\
\text { Self-limited (1) } \\
\text { Conservative (6) }\end{array}$ \\
\hline
\end{tabular}

WEN $\triangle$ in chinese, only abstract is available in English *WON and POP

4 after procedure. The second patient was a male of 44 years old with PPC of $15 \mathrm{~cm}$ who presented with abdominal pain and fever after 5 days of the drainage. The two patients with infectious adverse events were treated with a second EUS-GD using a nasocystic catheter with irrigation of $1000 \mathrm{~mL} /$ day of saline solution for 5 days with clinical and radiological resolution. The infection presented after the first procedure, regardless, both patients received prophylactic antibiotics.

\section{BLEEDING}

About the two patients who bled during endoscopic drainage, one of them was successfully treated endoscopically with clips and the second required surgery. No deaths related to endoscopic treatment were documented.

\section{Discussion}

According to our data staying one night in hospital, if were not any adverse events during the procedure, does not make a difference. If there is an adverse event, it happens immediately (bleeding and perforation) or days later (infection).

According to our results, in a previous retrospective analysis, only $32 \%$ of patients with EUS-GD required hospitalization ${ }^{12}$. Another study with 30 patients did not found any immediate adverse event procedure related, but four secondary infections were reported ${ }^{13}$. Siddiqui et al. reported a complication rate of $10.3 \%(n=9)$, they had 5 intraprocedural bleeding, three post-procedure pain, and one patient fever of uncertain etiology ${ }^{14}$. One RCT (2) with 20 patients with EUS-GD of PPC reported none adverse events in concordance to another study that compares EUS versus EGD ${ }^{7}$. In Table 3, complications reported in previous studies of EUS-GD of PPC are shown, as it can be seen in that table, of 15 studies reported, $2-23 \%$ of the total of complications are during the procedure or $<24 \mathrm{~h}$ later and the rest appears after more than 3 days.

The complication rate in our study was $16.1 \%$ and is according with previous reports $2,7,15-21$. For us, bleeding was the more important complication and we think that the use of needle knife to create a bigger fistula could explain this. Other authors recommend the use of a cystostome $6 \mathrm{~F}$ after initial puncture; however, unfortunately, this is not widely available in our country. We have two patients with infection of PPC after the initial drainage. The occurrence of post-puncture infections has been attempted to prevent with the use of prophylactic antibiotics; however, these are not 100\% effective. It is currently recommended that patients with pseudocysts with viscous debris-laden fluid the use of a nasocystic drain for the purpose of performing either "in bolus" or continuous lavage ${ }^{14}$. At this moment, there is no information on how long after drainage, the nasocystic drain must be in place or if there is any difference between doing them continuously or "in bolus." According to our experience, when PPCs are large $(>15 \mathrm{~cm})$ and the contents are clearly purulent, it is more appropriate to perform the washing through the nasoabscess catheter "in bolus" and not continuously, because at least in our experience, it causes a higher frequency of patients with systemic inflammatory response.

There are some limitations of our study; first, the retrospective design. However, for our knowledge, there is a lack of studies specifically focus on complications of EUS-guided PPC drainage ${ }^{21}$. Our data could be important for future study designs and reviews.

\section{Conclusion}

There is not a clear reason because patients with PPC and EUS-GD need for staying one night in hospital if was not any adverse event during the procedure. 
Disclosure: All authors disclosed no financial relationship relevant to this publication.

\section{Authors' Contributions}

Félix I. Téllez-Ávila design the study; Félix I. Téllez-Ávila and Miguel A. Ramírez-Luna were attending doctors and performed endoscopies; Félix I. Téllez-Ávila, Luis Eduardo Casasola-Sánchez, Angela Saul, Carlos Chan, Jorge Hernández-Calleros and Luis Uscanga-Domínguez organized the report; and Félix I. Téllez-Ávila, Luis Eduardo Casasola-Sánchez, Angela Saul, Carlos Chan, Jorge Hernández-Calleros and Luis Uscanga-Domínguez wrote the paper.

\section{References}

1. Varadarajulu S, Wilcox CM, Latif $S$, et al. Management of pancreatic fluid collections: a changing of the guard from surgery to endoscopy. Am Surg. 2011;77:1650-5.

2. Varadarajulu S, Bang JY, Sutton BS, et al. Equal efficacy of endoscopic and surgical cystogastrostomy for pancreatic pseudocyst drainage in a randomized trial. Gastroenterology. 2013;145:583-900.

3. Aljarabah M, Ammori BJ. Laparoscopic and endoscopic approaches for drainage of pancreatic pseudocysts: a systematic review of published series. Surg Endosc. 2007;21:1936-44.

4. Johnson MD, Walsh RM, Henderson JM, et al. Surgical versus nonsurgical management of pancreatic pseudocysts. J Clin Gastroenterol. 2009; 43:586-90.

5. Varadarajulu S, Lopes TL, Wilcox CM, et al. EUS versus surgical cyst-gastrostomy for management of pancreatic pseudocysts. Gastrointest Endosc. 2008:68:649-55.

6. Banks PA, Bollen TL, Dervenis C, et al. Classification of acute pancreatitis--2012: revision of the Atlanta classification and definitions by international consensus. Gut. 2013;62:102-11.
7. Varadarajulu S, Christein JD, Tamhane A, Drelichman ER, Wilcox CM. Prospective randomized trial comparing EUS and EGD for transmural drainage of pancreatic pseudocysts (with videos). Gastrointest Endosc. 2008;68:1102-11.

8. Park DH, Lee SS, Moon SH, et al. Endoscopic ultrasound-guided versus conventional transmural drainage for pancreatic pseudocysts: a prospective randomized trial. Endoscopy. 2009;41:842-8.

9. Varadarajulu S, Noone TC, Tutuian R, Hawes RH, Cotton PB. Predictors of outcome in pancreatic duct disruption managed by endoscopic transpapillary stent placement. Gastrointest Endosc. 2005;61:568-75.

10. Devière J, Antaki F. Disconnected pancreatic tail syndrome: a plea for multidisciplinarity. Gastrointest Endosc. 2008;67:680-2.

11. Varadarajulu S, Rana SS, Bhasin DK. Endoscopic therapy for pancreatic duct leaks and disruptions. Gastrointest Endosc Clin N Am. 2013;23:863-92.

12. Gibbs $\mathrm{CM}$, Baron TH. Outcome following endoscopic transmural drainage of pancreatic fluid collections in outpatients. J Clin Gastroenterol. 2005; 39:634-7.

13. Krüger M, Schneider AS, Manns MP, Meier PN. Endoscopic management of pancreatic pseudocysts or abscesses after an EUS-guided 1-step procedure for initial access. Gastrointest Endosc. 2006;63:409-16.

14. Siddiqui AA, Dewitt JM, Strongin A, et al. Outcomes of EUS-guided drainage of debris-containing pancreatic pseudocysts by using combined endoprosthesis and a nasocystic drain. Gastrointest Endosc. 2013;78:589-95.

15. Itoi T, Itokawa F, Tsuchiya T, Kawai T, Moriyasu F. EUS-guided pancreatic pseudocyst drainage: simultaneous placement of stents and nasocystic catheter using double-guidewire technique. Dig Endosc. 2009;21 Suppl 1:S53-6.

16. Sadik R, Kalaitzakis E, Thune A, Hansen J, Jönson C. EUS-guided drainage is more successful in pancreatic pseudocysts compared with abscesses. World J Gastroenterol. 2011;17:499-505.

17. Puri R, Mishra SR, Thandassery RB, Sud R, Eloubeidi MA. Outcome and complications of endoscopic ultrasound guided pancreatic pseudocyst drainage using combined endoprosthesis and naso-cystic drain. J Gastroenterol Hepatol. 2012;27:722-7.

18. Seewald $\mathrm{S}$, Ang TL, Richter $\mathrm{H}$, et al. Long-term results after endoscopic drainage and necrosectomy of symptomatic pancreatic fluid collections. Dig Endosc. 2012;24:36-41.

19. Kwon YM, Gerdes H, Schattner MA, et al. Management of peripancreatic fluid collections following partial pancreatectomy: a comparison of percutaneous versus EUS-guided drainage. Surg Endosc. 2013;27:2422-7.

20. Walter D, Will U, Sanchez-Yague A, et al. A novel lumen-apposing metal stent for endoscopic ultrasound-guided drainage of pancreatic fluid collections: a prospective cohort study. Endoscopy. 2015;47:63-7.

21. Kokosis G, Barbas AS, Li G, et al. Review of complications associated with endoscopic pancreatic cyst-gastrostomy: a single-institution experience. Surg Laparosc Endosc Percutan Tech. 2015;25:245-9. 